\title{
APOSTAS CRIANCEIRAS NA CONTRAMÃO DO DISCURSO COLONIZADOR NAS RELIGIÕES: o conto de Kiriku e a filosofia Ubuntu
}

\author{
Laíra Assunção Braga ${ }^{1}$ \\ Luiz Henrique Lemos Silveira²
}

\begin{abstract}
Resumo: O presente artigo objetiva apontar, a partir de epistemologias africanas, uma alternativa aos discursos e práticas, nomeados como intolerância religiosa, que possui números expressivos no Brasil. Partindo das análises históricas de investidas cristãs no Brasil colônia, entendemos que as lógicas coloniais encontram-se ainda imbricadas nos modos de viver religião no país. Consideramos, ainda, o adultocentrismo também como uma marca de colonização por um ideal de homem branco, adulto e cristão, um modelo europeu de existência. Desse modo, buscamos junto ao conto africano de Kiriku e à filosofia africana Ubuntu pautar o debate sobre outra forma de existência que nos permita coabitar na diferença, onde o desejo de domínio ou destruição que se encontram nas ações de violência de cunho religioso, dariam lugar a um modo crianceiro de abertura ao outro e a seus possíveis.
\end{abstract}

Palavras-chave: Intolerância religiosa; Colonização; Ubuntu; Kiriku.

\section{A CHILD MODE AGAINST THE COLONIZING DISCOURSE IN RELIGIONS: the tale of Kiriku and an ubuntu philosophy}

\begin{abstract}
The present article aims to point out, from African epistemologies, an alternative to discourses and practices named as religious intolerance, which are significant numbers in Brazil. Starting from the historical portfolios of Christian invested in Brazil colony, we understand that the colonial logics are still imbricated in the ways of living religion in the country. We also consider adultcentrism also as a mark of colonization by an ideal of white, adult and christian man, a european model of experience. In this way, they seek at the same time the challenge of Kiriku and the African philosophy Ubuntu set the dialogue about another form of existence that allows us to cohabit in difference, where the desire of domination or destruction in the actions of religious violence, create a new enrollment form.

Keywords: Religious intolerance; Colonization; Ubuntu, Kiriku.
\end{abstract}

\section{Introduzindo: O que Kiriku e Ubuntu têm a nos dizer em meio às violências entre religiões?}

Este texto se pretende enquanto uma articulação entre o conto africano de Kiriku, retratado em uma animação infantil de produção franco-belga-luxemburga, lançada no final da década de 1990 e a perspectiva africana da filosofia Ubuntu, como elementos possíveis para se pensar uma ética de diálogo inter-religioso, em meio às denúncias de ataques motivados pelo que é conhecido como intolerância religiosa no Brasil.

Kiriku é a aposta de que na criança reside uma capacidade para reinventar práticas, questionar discursos que já adquiriram estatuto de verdade e encarar situações adversas a partir da ludicidade, da brincadeira e da necessidade do outro. Em Kiriku,

\footnotetext{
1 Mestranda em Psicologia Institucional pela Universidade Federal do Espírito Santo. Graduada em Psicologia.

2 Pós-Doutorando em Ciências da Religião pela PUC Minas, Doutor em Psicologia pela PUC Minas, Mestre em Ciências da Religião pela PUC Minas. Atualmente, é Professor do Curso de Psicologia da Faculdade Pitágoras, em Teixeira de Freitas, Bahia.
} 
também encontramos o bem estar da coletividade como objetivo das ações do pequeno menino. Ubuntu, por sua vez, é uma filosofia, uma perspectiva de viver e se relacionar que considera a produção do bem comum como parâmetro para as ações.

Articulações entre Kiriku e Ubuntu também podem ser encontradas no trabalho de outros autores, como Noguera (2017), que enxerga na filosofia africana o apelo por uma noção da criança diferente da ótica ocidental racionalista. Nesse ponto, também entendemos que Ubuntu permite conexões com o conto retratado no filme Kiriku. Ambos apresentam ainda, a origem africana subsaariana como comum. Trata-se de uma região cujos modos de pensar e operar são pouco convocados na produção de conhecimento, pois também somos nutridos por um consumo constante de saberes europeus. Dar força para Kiriku e Ubuntu é uma forma de compor novos sentidos éticos buscando outras epistemologias, não centralizadas na produção hegemônica do saber ocidental colonizador.

Nem a perspectiva Ubuntu, nem o conto de Kiriku propõem uma religiosidade ou crença específica, com pretensões universais. São essas atitudes desapegadas de verdades universais que buscamos para pensar pontos de convergência, uma proposta de convivência entre os diferentes saberes religiosos que operam em nossa sociedade.

$\mathrm{Na}$ contramão de alguns usos do cristianismo, que parecem se ocupar de dizer sua verdade como única, inferiorizando práticas dissidentes e produzindo segregação, Ubuntu e Kiriku vêm nos contar outros possíveis. Para pensar essa empreitada é necessário, primeiramente, compreender que o que atacamos não é alguma prática religiosa específica, mas a urgência de se afirmar um discurso sobre outro. Conforme pontua Noguera (2017), apostamos em caminhar junto a muitas racionalidades possíveis, sem a hierarquia de qual perspectiva seria mais legítima.

Ainda com Noguera (2017), pensamos também em outra dimensão da infância, tomada a partir da afroperspectiva. O autor se ocupa de encontrar em Kiriku e Ubuntu, elementos para pensar uma infância inventiva, contrária aos modos de tutela que encontramos na perspectiva branca ocidental. Noguera (2017) junta Kiriku e Ubuntu para pensar processos educativos.

Nossa proposta segue por um caminho de tentar trazê-los para anunciar uma ligação possível entre os saberes religiosos, uma ética que não seja de domínio e convencimento, mas de integração e produção de coletividade para além do mundo espiritual que cada religião possa elucidar, mas pensando no aqui, neste mundo terreno que habitamos no presente. 
Antes de qualquer descrição possível da animação que retrata o conto de Kiriku, é fundamental pontuar que em um site de grande circulação na exibição de vídeos do Brasil, nos deparamos, no momento em que foi acessado, em janeiro de 2019, com a mensagem de que "este conteúdo pode ser impróprio para alguns usuários”. Encontrar essa mensagem já produz alguns questionamentos do que pode ter sido considerado ofensivo na animação, considerando que trata-se de uma produção direcionada ao público infantil. Durante o texto, ficam algumas indicações do que pode ter sido visto como conteúdo impróprio.

Desta forma, entendemos a relevância deste trabalho para repensarmos o que se conhece como intolerância religiosa, tão presente em nosso país. Contudo, não esperamos esgotar possibilidades de discussão do filme Kiriku e da filosofia Ubuntu. Intentamos, pela ótica crianceira de Kiriku sobre o mundo, contribuir para movimentos que deslocam as relações entre religiões do desejo de verdade, de universalidade, de dominação e imposição. Para tanto, iniciaremos com um apanhado histórico do lugar que o cristianismo ocupou desde que foi iniciada a colonização das terras brasileiras. Posteriormente, apresentaremos o conto de Kiriku e uma breve discussão da filosofia Ubuntu. Por fim, buscamos os pontos em comum, para fomentar o exercício de descolonizar as relações entre as religiões e seus praticantes.

\section{Brasil Cristão: usos colonizadores do cristianismo}

O Governo Federal divulgou, a partir do censo do IBGE de 2010, haver mais de 40 grupos religiosos registrados no país. Quando lemos "registrados" é importante pensar que podem haver tantas outras práticas religiosas que ainda não alcançam esse registro, mas, nem por isso, deixam de possuir efeitos na vida das pessoas e comunidades em que se inserem. Encontramos ainda o dado de que mais da metade da população que declara religião, se diz cristão (BRASIL, 2018). Essa informação não provoca espanto, justamente por histórica e culturalmente estarmos acostumados às marcas do cristianismo espalhadas pelas cidades, pelos feriados nacionais e até em atos públicos que realizam práticas e orações cristãs. Existe o pressuposto da laicidade pressuposto em nossa organização social, mas não podemos negar o peso do cristianismo na constituição dos povos brasileiros.

Essa realidade torna-se compreensível quando acessamos a constituição histórica do solo brasileiro, considerando que o processo de colonização miscigenou a invasão comercial portuguesa, com a missão religiosa cristã, não só no Brasil, como em 
outros países. Nesta mesma linha de raciocínio, Vainfas e Souza (2002) afirmam que:

Terra de Vera Cruz, verdadeira Cruz, depois Terra de Santa Cruz, a cruz santa, assim se chamou o Brasil, nos primeiros tempos, após a chegada dos portugueses em Porto Seguro. Apesar dos nomes, a expansão ultramarina portuguesa foi, sem dúvida, motivada por razões comerciais. As especiarias da Î́ndia, sedas, cravo, canela, pimenta. Antes disso, o ouro do Sudão, depois, escravos da Guiné. Não obstante, a cruz de Cristo guiaria os portugueses desde Ceuta, conquistada em 1415, primeiro alvo da conquista ultramar. (VAINFAS; SOUZA, 2002, p. 7)

Deste modo, entendemos que, por ambições comerciais e territoriais, foram feitos usos do cristianismo com justificativas de que as embarcações portuguesas tinham povos a salvar, a verdade cristã para propagar. Celebrações de rituais cristãos, nomeação das terras com símbolos católicos, missões jesuítas deram o tom religioso à tomada de terras.

O sentido religioso da expansão ultramarina, empenhado, como no cruzada, (em alargar os territórios dos fiéis ao Cristo, se transmutaria depois na ideia de missão, ora empenhada na salvação das almas. Almas d'além mar, mais do que territórios da cristandade, eis o que passou a preencher o sentido religioso da colonização. E isso não só no Brasil como no Oriente, a terra das especiarias, para onde foi o jesuíta Francisco Xavier, jesuíta que, por seu denodo missionário, virou santo. E também a África, o grande empório de escravos, foi objeto de evangelização, sobretudo o Congo e a Angola dos Banto. (VAINFAS; SOUZA, 2002, p. 8)

A colonização não se efetivou apenas no nível territorial, mas, também, subjetivo, religioso e político. Não é difícil admitir que existe uma construção de pensamento bastante eficiente ao pensarmos a história do Brasil e dos povos desta terra considerando apenas os pouco mais de 500 anos de chegada dos portugueses. O Brasil na noção europeia de civilidade e racionalidade, existe apenas nesse recorte temporal. Isso não se deu à toa. A investida messiânica do império português conseguiu êxito empenhando esforços em dizer de suas práticas como as verdadeiras, as civilizadas e, de modo peculiar, sua religião como a única legítima. Cotidianos que antecederam o processo de colonização foram se enfraquecendo e a história não nos diz de diálogo ou de alguma tentativa curiosa de entender o que se passava nestas terras, mas sim, de dominação e convencimento do outro, se utilizando, dentre outras coisas, da verdade cristã, para que se atingissem meios de exploração comercial e de força de trabalho.

Vainfas e Souza (2002) relatam que há dados históricos de que os índios eram vistos como povo sem fé, sem uma organização de comunidade, sem civilidade. Mas 
estas impressões enfrentaram resistência entre pessoas e modos de vida que, pelo que constam os relatos de lutas, não pareciam estar à espera de alguma embarcação messiânica que os trouxessem um discurso mais legítimo e confiável do que os seus próprios.

Mesmo diante de resistências, os esforços se deram no sentido de evangelizar e educar. Aqui notamos que a atual noção de educação eurocentrada e racionalista já apresentava sinais. Uma educação que considera no outro um não saber, que retira a autonomia, que interfere nas tradições em busca de homogeneização, uma educação assassina de modos de vida. $\mathrm{O}$ cristianismo, enquanto religião, foi utilizado a todo o tempo nessa missão política. "Em certos documentos, vemos os padres tentando desmerecer os que chamavam 'feiticeiros', os pajés da cultura tupi, que agiam como curandeiros ou presidiam grandes cerimônias de comunhão com ancestrais mortos". (VAINFAS, SOUZA, 2002, p. 13).

Vainfas e Souza (2002) ressaltam que a catequização parece ter sido mais incisiva sobre as práticas religiosas indígenas. Faz-nos considerar que o povo detinha uma organização no território e poderia apresentar maior resistência aos interesses, como de fato o fizeram. Já a escravidão trouxe corpos já dominados e com interesses que se mantivessem como força de trabalho. Desse modo, a vigilância e aplicação de punições para os escravos, no que diz respeito às suas expressões religiosas, deixavam algumas coisas mais frouxas (VAINFAS, SOUZA, 2002). Mesmo assim, ainda foi possível configurar o discurso racista em tornos das religiões afro. O único exercício religioso a adquirir estatuto de legitimidade foi o cristianismo, sendo o católico, de longe, o mais influente.

Vemos com isso que não é à toa que a maioria dos que se declaram cristãos no Brasil, o fazem pelo catolicismo. Também não é difícil entender, a partir da história, como se articulou a produção discursiva de inferiorização de religiões afrodescendentes, dando a elas lugares periféricos, longe dos templos cristãos ornamentados e evidentes nas praças públicas. Se tratando da religiosidade dos povos indígenas, pouco se fala e pouco se encontra sobre, demonstrando as investidas genocidas de mais de 500 anos de apropriação de terras indígenas. Nesta direção Laraia, aponta que:

Judaísmo, cristianismo, islamismo, budismo e hinduísmo são exemplos de grandes religiões, que possuem muitos adeptos, porque passaram por um longo processo de globalização. Existem, porém, numerosas outras 
religiões que ficaram à margem desse processo. É o caso das religiões das chamadas sociedades indígenas. No Brasil são muito numerosas e pouco estudadas. (LARAIA, 2005, p. 7)

Não é nosso objetivo exaurir a elucidação dos elementos históricos de como a religião cristã foi utilizada politicamente. Todavia, o percurso histórico buscado e os dados religiosos da atualidade nos sugerem indícios de que a colonização cristã, como instrumento de poder, funcionou bem, tornando esta a religião com maior número de fiéis no Brasil.

A partir disso, ficamos com a questão: além de se constituir como vinculação e prática que todo cidadão tem direito de exercer, a religião ainda continua sendo utilizada como instrumento de dominação, de inferiorização da diferença e assassinato de certos modos de vida?

Apontamos a perspectiva de que o uso colonial da religião conseguiu se atualizar e mantém relações com a violência que é noticiada (ou não) na imprensa. $\mathrm{O}$ jornal O Estado de São Paulo, em novembro de 2017, divulgou dados do antigo Ministério dos Direitos Humanos, que agora é Ministério da Mulher, da Família e dos Direitos Humanos, sobre intolerância religiosa no Brasil. Na reportagem, vemos que no período 2015 - 2017, uma denúncia foi registrada a cada 15 horas, sendo as religiões de origem africana as maiores vítimas, $39 \%$ em uma análise do ano de 2017. A reportagem alerta, ainda, para a possibilidade de muitas denúncias permanecerem no silêncio, pois não são feitas. (RESK; TOMAZELA; COTRIM, 2017)

Os dados estatísticos, aliados aos relatos de que as violências se dão de modo pessoal ou até mesmo pela destruição de templos e símbolos sagrados, nos mostram que ainda há uma prática de condenação de religiões que se coloquem em lógicas diferentes da cristã tradicional. Além de condenar, parece haver uma intenção de destruição, um desejo de desaparecimento da diferença. A necessidade de afirmar uma verdade sobre tantas outras se imprime a partir da violência. (NASCIMENTO, 2010)

Como visto, tais práticas possuem um caráter sócio-histórico, considerando que, desde as primeiras embarcações portuguesas que chegaram nesta terra, a força e a dominação foram as estratégias utilizadas para a conversão dos que aqui já habitavam. O exercício do cristianismo tornou-se prática legítima, colocando às margens outras expressões religiosas. Nascimento (2010) nos apresenta uma discussão considerando o racismo um dos principais motivos da subalternização das religiões de matrizes africanas no Brasil. A autora ressalta que o movimento de inferiorização dessas práticas 
pode ser encontrado até em estudos sobre o fenômeno religioso, em determinados períodos históricos. Ela aponta que:

Como reflexo da marginalização e discriminação reservada ao negro em nossa sociedade, as manifestações de religiosidade afrobrasileiras, por serem religiões de transe, de culto aos espíritos e em alguns casos de sacrifício animal, têm sido associadas a estereótipos como o de 'magia negra', (por não apresentarem geralmente uma ética voltada para uma visão dualista do bem e do mal, conforme estabelecem as religiões cristãs tradicionais), superstições de gente ignorante, práticas diabólicas, etc. Alguns desses atributos foram inclusive reforçados pelos primeiros estudiosos no século XIX, que sofreram fortes influências evolucionistas e tradicionalmente baseiam sua produção historiográfica no modelo monoteísta cristão que denominavam 'superiores', e que tendem a classificar as religiões de matrizes africanas como formas "primitivas" ou 'atrasadas' de culto. (NASCIMENTO, 2010, p. 924)

As investidas coloniais, em suas diversas manifestações, incluindo as religiosas, implicaram em um certo triunfo do cristianismo católico. Uma das estratégias de conversão, como temos percebido, foi a produção discursiva de legitimidade e de verdade sobre o cristianismo. Só se aceita uma perspectiva como verdadeira e só a ela é dada o direito ao aparecimento.

Trata-se de uma demanda que entendemos como sendo do sujeito racional, que pauta suas práticas pela busca do verdadeiro, possibilitando que se configure uma relação de disputa, em que interessa mais a afirmação ou vitória do discurso verdadeiro, do que os sentidos e afetos que a relação suscita. Nos encontramos imersos no desejo de verdade. Sobre a vontade da verdade, Foucault, afirma que:

Assim, só aparece aos nossos olhos uma verdade que seria riqueza, fecundidade, força doce e insidiosamente universal e ignoramos, em contrapartida, a vontade de verdade, como prodigiosa maquinaria destinada a excluir todos aqueles que, ponto por ponto, em nossa história, procuraram contornar essa vontade de verdade e recolocá-la em questão contra a verdade, lá justamente onde a verdade assume a tarefa de justificar a interdição e definir a loucura; todos aqueles, de Nietzsche a Artaud e a Bataille, devem agora nos servir de sinais, altivos sem dúvida, para o trabalho de todo dia. (FOUCAULT, 1996, p. 20)

Deste modo, como convivemos politicamente com a herança de costumes europeus, também os vivenciamos religiosamente, tendo como modelo o adulto, branco e cristão. Os dados estatísticos e narrativos nos mostram que esse modelo não consegue responder a toda pluralidade de expressões religiosas e se mantém, por vezes, pela imposição. Como Foucault (1996, p. 51) também nos indica é preciso “questionar nossa 
vontade de verdade". Sendo assim, pensamos que uma aposta a ser investida seria desviar o olhar, buscar outras epistemologias e outros sentidos para as práticas comunitárias, inclusive as religiosas, visando um mundo onde a vida seja o que interesse e não a colonização do outro. A seguir, apresentamos o conto de Kiriku, a partir de uma produção cinematográfica de animação, como um contraponto e um indicador de outras racionalidades a serem consideradas, por uma perspectiva de criança.

\section{Kiriku: Um menino revolucionário}

A animação conta a lenda de Kiriku, na África subsaariana. Um menino ainda pequeno que torna-se guerreiro e faz investidas na busca de libertar sua vila dos domínios de uma feiticeira, que é tomada em grande parte do filme como a força do mal. As cenas e falas trazem a simplicidade que o filme parece querer imprimir.

Um fato que faz pensar o vídeo ter sido tomado como conteúdo impróprio são as vestimentas das mulheres. Elas aparecem, em sua maioria apenas com uma saia, expondo os seios com diversas formas e tamanhos. A feiticeira, que também expõe os seios, aparece ainda com enfeites nos mamilos, destacando-os esteticamente. Daí já percebemos que outros regimes estão em pauta. A relação com a exposição do seio feminino não possui o mesmo sentido interdito e erotizado que estamos habituados.

Dizemos que Kiriku torna-se guerreiro e o fazemos a partir da consideração de uma processualidade que se dá na história. O pequeno nasce com habilidades especiais, como a fala precoce. Mas o que poderíamos chamar de sua missão não está dada, ela vai se construindo na medida em que o pequeno conhece a realidade de sua vila e se incomoda com as dificuldades que seu povo enfrenta em decorrência da maldade da feiticeira.

Entendemos que Kiriku torna-se uma figura messiânica, mas partindo da realidade do seu povo. Sem um manual de instruções que norteiam suas ações e em relação de desvantagem, em certas situações, com as pessoas adultas, Kiriku vai travando embates cotidianos com as investidas do que é considerando "o mal".

Não há em Kiriku uma referência parental direta para nortear suas ações. Ele e sua mãe demonstram uma relação que escapa da tutela e assume contornos de parceria e de horizontalidade. A figura do seu pai é salva da situação de aprisionamento a partir dos atos do pequeno, uma inversão de posições em que a criança assume um outro 
lugar, bem diferente da referência de criança carente do saber e cuidado adultos.

Ora acolhido, ora desprezado, Kiriku aponta uma noção de coletividade como fio condutor de suas ações. Kiriku funciona a partir de uma produção de comum como quando adentra por um espaço que só comporta seu corpo pequeno, para derrotar um monstro que sugava a água da comunidade. O monstro é grande, mágico e provoca medo, mas Kiriku não se contentou em apenas assistir à ação maléfica, ele a questionou. O filme retrata que o menino retorna morto dessa missão, mas, misticamente, é também o povo junto cantando, que o traz de volta à vida. O popular atravessa o conto todo o tempo.

Kiriku consegue liberar água da fonte para seu povo e neste ato adentra um espaço proibido até então. Foi, inclusive, alertado sobre tal proibição. A feiticeira proibiu pessoas de entrarem na fonte que era vista e nomeada como fonte maldita. É possível perceber a dimensão do sagrado colocada como elemento de composição da maldição da fonte. Segundo Rodrigues (1983, p. 25):

O ser sagrado é o ser proibido que não pode ser violado, do qual não ousamos nos aproximar, porque ele não pode ser tocado. Está permanentemente protegido desse contato pelas interdições que o isolam e protegem do profano. Tudo o que é sagrado existe à parte: não pode ser colocado em pé de igualdade com o que é profano e muito menos estar com ele misturado.

O autor, Rodrigues (1983), nos diz que o contato indevido com o sagrado resulta em sua profanação. Atrevido que foi, podemos sim pensar que Kiriku profanou a fonte maldita, a fonte que ninguém poderia entrar pelo temor do que poderia a feiticeira aplicar como punição. A barreira do sagrado foi então vencida e a fonte se tornou acessível e útil. Uma fonte profanada, direcionada ao bem comum.

Rodrigues (1983) nos ajuda a entender o sagrado não somente como algo relacionado à pureza ou à veneração, mas, também, como o que não deve ser tocado, o que não deve ser acessível. Para que o sagrado se mantenha de tal forma, o tabu é configurado e estabelece a lógica punitiva para quem transgride as fronteiras (RODRIGUES, 1983).

No caso de Kiriku, a fonte era espaço proibido e a punição seria a morte, o que de fato se concretizou no filme, mas o povo cantou para Kiriku reviver. Aqui, temos outro elemento para pensar uma ética de responsabilização coletiva. Foi a força do povo quem deu vida novamente à Kiriku. Não há, na animação, referência à uma força exterior ao povo. 
Kiriku questiona diversas coisas o tempo inteiro. Os conhecidos "por que" das crianças comparecem com destaque na história. Questiona ao ponto de rejeitar explicações simplistas sobre a maldade da feiticeira. Ele quer entender o que a motiva a fazer o mal, o que a direciona na destruição de outras pessoas. Nessa busca, ele chega até seu avô, um sábio que vive nas montanhas, pois ele parecia poder lhe contar as motivações da feiticeira. Lá ele escuta que o medo é quem faz a feiticeira parecer tão poderosa e que o dualismo entre perigo e proteção é capaz de enganar e iludir as pessoas. Finalmente, ele descobre que a feiticeira pratica maldades porque sofre. Ela tem um espinho que lhe foi cravado nas costas tempos atrás e esse espinho lhe provoca muitas dores e lhe dá poderes. Ela precisa de alguém para tirá-lo, mas tem medo de tornar a sentir dor intensa, o que a impede de pedir ajuda a alguém.

Havendo compreendido a maldade da feiticeira e o que então deveria ser o foco de sua intervenção, Kiriku pede colo ao avô, um momento de carinho e aconchego. Com muita habilidade, o pequeno circula entre papéis que, no endurecimento adulto, podem soar contraditórios. Ele pode ser corajoso, carinhoso, divertido, responsável, sem desconforto ou constrangimento nas alternâncias ou hibridizações dos movimentos.

Kiriku nos diz de um modo outro de lidar com o perigo. Uma outra ética para se relacionar com o que é tomado como mal surge quando ele o questiona e compreende a possibilidade de desconstrução desse elemento. Enquanto os adultos parecem aceitar as condições ruins e os feitiços colocados na vila pela feiticeira, ele se incomoda, não só com os produtos do mal, mas com a motivação para que ele se dê. A maldade deixa de ser condição inerente à pessoa e passa a ser encarada como produção de realidade a ser combatida.

O conto é permeado por misticismos e alguns pontos de feitiçaria, de encantamento, mas em nenhum momento é possível atribuir a esta ou àquela religião o contexto espiritual que ali existe. Isso torna o conto um exercício de pensamento podendo se aplicar às muitas concepções, inclusive religiosas. A espiritualidade em Kiriku faz sentido na imanência, na realidade e no cotidiano do mundo que se tem.

No final da animação, Kiriku se transforma em um homem, mas entendemos que ele preserva em si a criança. Ele se casa com a feiticeira, provocando espanto e indignação nos seres adultos da comunidade, ele consegue escapar do ato de condenação da feiticeira e constrói com ela uma aliança para uma outra realidade para todos.

Kiriku conta-nos outras histórias sobre a relação com a natureza; com o medo; 
com o bem e o mal e suas sacralidades. Ele nos interessa para produzir contrapontos em uma sociedade que exalta o adulto como existência madura e racional, sendo essa mais uma herança colonial europeia. Também nos interessa pensar com Kiriku a capacidade da criança escapar das lógicas condenatório e estar com outro em regime de cooperação. Kiriku não luta para eliminar a feiticeira, ele luta para eliminar a realidade que dá condições para que o mal aconteça. Isso só parece ser possível pois Kiriku não tem certezas, ele tem curiosidade e abertura para o mundo, uma potência que reside na criança.

\section{Ubuntu: uma busca pela coletividade}

É difícil encontrar uma definição que se pretenda completa e derradeira para o conceito de Ubuntu. Ficamos aqui com a noção de que se trata de uma filosofia de origem africana e que trabalha considerando que práticas e discursos devem ser norteados pela interdependência entre todos os seres que constituem o universo. A questão central trata de que cada existência só é possível a partir de outras existências (NOGUERA, 2017). Mogobe Ramose, principal referência filosófica do Ubuntu, diz que esta consiste em conceitos de povos que falam línguas Bantu, localizados na África subsaariana.

O Ubuntu é um dos conceitos filosóficos e dos princípios organizacionais essenciais das populações que falam línguas Bantu. Estas populações precisam, face à globalização econômica, cimentar fortes vínculos de solidariedade, em primeiro lugar, entre elas mesmas. (RAMOSE, 2009, p. 139)

Pensar Ubuntu constitui encarar estar no mundo na contramão do discurso colonial do convencimento e dominação do outro, da exploração desenfreada de recursos da natureza pautando sempre a ideia de que alguns seres são servis a outros. Ubuntu anuncia que é possível estabelecer um regime de cooperação e, como discute Noguera (2017), que não tenha como pretensão a universalidade, ou o reconhecimento de uma única verdade.

Pensamentos e práticas podem ser partilhados e não disputados. Desse modo, a hierarquia entre seres e saberes perde sentido e entra em cena o que Noguera (2017) discute como polirracionalidade. Esta seria uma forma de não reduzir a razão a uma só, nem a um modelo, nem a um estágio de vida. 
Dentre outros desdobramentos possíveis, as polirracionalidades nos interessam para pensar alternativas ao pensamento adultocêntrico que sustentam certos modos de encarar e experimentar as práticas cotidianas, dentre elas, as religiosas. A idade adulta produtiva é considerada o estágio humano de maior razoabilidade, em que o sujeito adquire toda a capacidade de avaliar, decidir e agir sobre o mundo. Perdura, aí a dominação e sujeição de uns em relação aos outros, os que podem falar e planejar o mundo, pois detêm a razão plenamente desenvolvida e os que não podem, geralmente localizados no sujeito criança. Mesmo na relação entre adultos, a urgência de afirmar a verdade em cada discurso, promovem uma relação de disputa, uma relação excludente.

Trata-se de um funcionamento eurocêntrico, em que o pensamento e a razão são tomados como as fontes de um verdadeiro conhecimento de si e do mundo. Geralmente tudo isso no singular. Um pensamento, uma razão, um conhecimento e um mundo. Ubuntu apresenta-nos um outro modo de se relacionar, em que os sentidos comparecem como forma de experimentar e validar os diversos mundos e a racionalidade adquire sentido nas relações, desse modo, podem ser muitas.

O famoso 'penso, logo existo' proferido por Descartes, onde a existência do ser humano está condicionada ao pensamento, é aqui na 'filosofia ubuntu' contraposto por algo eminentemente diferenciado, 'sou por que vós sois’. (ROCHA; SILVA; ALBUQUERQUE, 2013, p. 173)

Pensar Ubuntu é, também, um pensar crianceiro, é operar pela curiosidade e pela condição de existência da diferença. Noguera (2017) busca na língua Zulu, uma das línguas do grupo Bantu, a palavra Ubuntwana para dizer de um cultivo da ideia de infância, independente da faixa etária do corpo. Seria o resgate constante da capacidade de reinventar e produzir novas realidades. Pela Ubuntwana, Noguera (2017) consegue aproximar uma educação Ubuntu e o filme Kiriku:

Kiriku é a pessoa que mais vive essa dimensão da infância, isto é, a potência de reinterpretar o mundo e se ocupar dos sentidos possíveis ao invés da verdade. Uma educação ubuntu valoriza a produção de sentidos, um exercício voltado mais para o cultivo da infância (ubuntwana). Ou seja, um investimento nas condições de possibilidade de reinaugurar a realidade. (NOGUERA, 2017, p. 117)

\section{Kiriku e Ubuntu: coabitar na diferença}

Noguera (2017) fez a articulação entre Kiriku e Ubuntu para pensar a criança e práticas educativas de modo mais autônomo e colaborativo, marcando politicamente a 
posição da afroperspectiva na construção das visões do mundo. Concordamos que Kiriku é uma das expressões possíveis de criança Ubuntu e nosso objetivo consiste em retomar essa articulação como um convite para pensamentos mais solidários e cooperativos em meio ao contexto da dita intolerância religiosa no Brasil.

Nosso objetivo adquire contornos aqui. Pensar uma proposta ética alternativa ao ódio e à intolerância. Para isso, é necessário assumirmos que qualquer imposição de prática religiosa ou de verdade dogmática se tornará problemática. Mesmo partilhando a mesma expressão de fé, o ser humano é plural e suas relações com o sagrado e o profano podem se dar de diversas formas. Como pensar uma organização dessa coletividade tão múltipla? O que é possível produzir de comum?

Convocamos Kiriku e Ubuntu para pensarmos juntos, a partir de uma realidade minoritária, uma realidade preta. As produções, de origem africana subsaariana, partilham atravessamentos, começando pela origem geográfica. Em Kiriku é possível perceber, como aponta Noguera (2017), elementos da filosofia Ubuntu. Nem o conto, nem a filosofia estão ligadas diretamente a nenhuma religião específica, mas carregam em si a capacidade de interpretar o mundo, os seres vivos, a diferença e até a maldade por uma ótica em que mais se compreende do que se condena.

Não por coincidência, trazemos material preto para conversar e pensar alternativas para um processo de colonização, neste caso religioso, embranquecido e segregacionista. Não por acaso, buscamos em Kiriku a expressão crianceira genuína de transformar a realidade, de reinventar a monstruosidade, o sagrado, o feitiço, o mal, pensando muito mais no bem comum, do que na simples afirmação de uma perspectiva. Também não é à toa que enxergamos, junto com Noguera (2017), que a prática Ubuntu é, também, um exercício de retornar à criança.

$\mathrm{O}$ adulto que domina, que pensa deter todo saber e verdade também aparece nas religiões. Acreditamos ser possível uma ética de criança curiosa, solidária e que se perceba dependente do outro para continuar existindo, desse modo, não cabem a destruição do outro ou de suas práticas. A relação de interdependência suscitada apresenta-se como norteador de ações para que as diversas religiosidades convivam sem destruição.

Dizer isso não indica buscar em Kiriku e Ubuntu posturas próximas de um humanismo, mesmo porque ambas as produções apontam que mesmo elementos não humanos são igualmente relevantes no funcionamento do mundo. Isso também poderia se tornar uma cilada, na medida em que a noção de humano é algo que pode variar a 
ponto de, em algumas situações, um corpo poder tornar-se monstruoso, perdendo o direito aos acessos concedidos aos reconhecidamente humanos. A disposição ao outro, vista em Kiriku e Ubuntu, extrapola as noções do humano, atinge a vida em sua multiplicidade.

Pensar Kiriku e Ubuntu também não se resume a entender a solidariedade como um ato de doação individual. Vai além, pois é a compreensão de que eu existo a partir do outro, em constante ligação, colocando a própria noção de sujeito individual em questão. Neste aspecto, também é um contraponto com uma ideia de caridade de indivíduo para indivíduo, que pode ser percebida em certos contextos religiosos.

Em uma realidade de desigualdade social, como enfrenta o Brasil e sendo este um país predominantemente cristão, presenciamos diversas campanhas encabeçadas por igrejas, para levar comida, utensílios e mensagens bíblicas até os espaços e sujeitos marginalizados, atos considerados como prática caridosa. Souza (2001), dentre outros autores, discute em sua tese de doutorado a caridade como um conceito geralmente associado ao cristianismo. Ele ainda aponta que a caridade é vista como expressão de amor a Deus, assumindo, por vezes, uma espécie de condição para se chegar ao transcendente.

O resultado buscado pela prática caridosa, nos moldes do cristianismo seria a salvação. A dimensão da vida enquanto importância comparece, mas como um meio e não um fim em si. Sendo a caridade um passaporte para a espiritualidade, as condições para que ela seja praticada, precisam continuar acontecendo. Mais reprodução do que transformação social.

Na relação proposta entre Kiriku e Ubuntu, os contornos desse tipo de caridade são abandonados. Não se trata de fazer o bem pensando apenas em um prêmio final, aos moldes da salvação da alma. Mas, por outro lado, trata-se criar condições onde a vida seja possível para todos. É a vida que interessa. Sobre Ubuntu, Rocha, Silva e Albuquerque (2013, p. 175) dizem:

Neste sentido, a bondade é exaltada num sentido cada vez menos convencional, não se trata de ofertar, doar recursos ou fazer das outras pessoas um objeto da caridade individual. Mas, significa trabalhar junto e fazer do resultado dos esforços um campo vasto para movimento e proveito de todas as pessoas.

Essa concepção Ubuntu de prática do bem, numa dimensão coletiva, pode ser encontrada em Kiriku diversas vezes. O menino não se contenta com as explicações 
sobre o mal e sobre sua continuidade, enquanto muitos sofrem. O episódio da fonte de água é o mais significativo a esse respeito. Toda a comunidade sofrendo, mas as ações adultas eram só de reprodução do relato de maldição, incapacidade de ação e aceitação, ao mesmo tempo, de uma condição que afetava a todos.

Kiriku, inquieto, se propôs a tentar. Como as crianças por vezes o fazem, ele foi desobediente. Conseguia passar pela pequena entrada da fonte por ser pequeno e assim fez proximidade com a monstruosidade que sustentava a maldição. A coletividade é positivada a todo o tempo em Kiriku e superou o lugar sagrado atribuído à fonte, para um benefício comum, terreno e humano. Esse ato, visto como bom para a comunidade não foi um meio, mas o fim em si.

O que almejamos é provocar, com Kiriku e Ubuntu, a urgência de que as religiosidades busquem, para além de suas crenças, traçar regimes de relação considerando nossa humanidade plural. Sair da disputa discursiva, certamente, parece ser um dos primeiros passos.

A solução que Kiriku busca para os feitiços que assolam a vila são imanentes à situação. Ele age sobre, a partir do que é dado. Os momentos em que o menino questiona o mal são os maiores indicadores de uma ética em que a curiosidade e a atenção vêm antes da condenação. Ele é o único que se aproxima do mal, que é visto na feiticeira, para interromper seu ciclo ajudando-a. Kiriku não a destrói enquanto sujeito, ele lhe retira o espinho das costas. Não há busca de regras ou elementos universais que poderiam entregar um modo único de agir. Kiriku, de um jeito crianceiro genuíno, reinventa o feitiço e só assim consegue agir para que ele tenha fim sobre o corpo da feitiçeira. "Kiriku é a pessoa que mais vive essa dimensão da infância, isto é, a potência de reinterpretar o mundo e se ocupar dos sentidos possíveis ao invés da verdade." (NOGUERA, 2017, p. 116)

Felizmente, há situações que nos mostram que são possíveis outros modos de coabitação. O jornal virtual BBC, publicou em Abril de 2018, matéria noticiando sobre um grupo liderado pela pastora Lusmarina Campos, de uma igreja cristã protestante. O grupo arrecadou valores e acompanhou a obra de reconstrução de um terreiro de candomblé, religião de matriz africana, destruído em Duque de Caxias - RJ. Durante a reportagem, há falas de pessoas de ambas as religiões e chama atenção o modo como a pastora encara a diferença, pela vida da proximidade e cuidado com o que lhe aparece como alteridade. A pastora ainda situa o caráter político do crime, como um projeto de poder onde não há respeito e se pressupõe que o outro está errado, um ataque à 
diversidade. (ATHAYDE, 2018). Nesta mesma direção, Teixeira afirma que:

Nesta nova perspectiva, as tradições são colocadas diante de uma dupla opção: ou a recusa do engajamento discursivo e da comunicação ou a abertura dialogal. A escolha da primeira opção implica muitas vezes a assunção do fundamentalismo, que consiste na 'defesa da tradição de forma tradicional', em reação às novas circunstâncias da comunicação global. A segunda opção da comunicação dialógica, impõe-se, hoje, como um dos desafios mais fundamentais da humanidade. (TEIXEIRA, 2008, p. 70).

O caso do crime e posterior auxílio prestado nos serve de exemplo para o que temos pensado. Não é necessário abandonar ou destruir a especificidade de cada prática religiosa, para que essas estabeleçam regime de cooperação. Para que isso se torne frequente, é urgente que religiões hegemônicas escapem do desejo de colonizar e convencer o outro. Retornar à criança que não grita por certezas, mas por sentidos e afetos, como bem disse Noguera (2017, p. 117): “ reinaugurar a realidade” ao invés de buscar uma única noção de real, é o convite que deixamos para os diversos contextos onde se falam de religiões, seja ele a escola, a igreja ou tantos outros.

\section{Considerações finais}

Compreendemos que o processo de colonização europeia foi efetivo e deixou marcas persistentes sobre as práticas dos povos brasileiros. A constituição de uma maioria cristã no Brasil é uma dessas marcas. O modo como a criança é encarada também guarda vestígios de um ideal de homem europeu, centrado na razão e na busca pelo discurso mais legítimo.

Dessa forma, buscamos, no conto de Kiriku e nas considerações de Noguera (2017) acerca da ubuntwana na filosofia Ubuntu, pensar uma potência de reinvenção da realidade a partir da criança. Kiriku ousa agir sobre o sagrado pelo bem do seu povo e questiona o que é o mal. O menino consegue, pela via da proximidade, ajudar a feiticeira a sair da condição que a demonizava. Kiriku, neste caso, é a personificação da potência ubuntwana de pensar e viver a realidade a partir do sentimento de coletividade e interdependência.

O que tudo isso pode nos dizer sobre relações inter-religiosas?

Em um país pautado por heranças europeias que incluem o adultocentrismo, a racionalidade e o cristianismo e que apresenta dados tão relevantes de violência em virtude da diversidade religiosa, é urgente que questionemos quais relações têm sido 
produzidas e como elas interferem na produção dessa violência. O desejo pela afirmação de discurso verdadeiro, de prática mais legítima, parece sustentar o enrijecimento de certas religiões ao olhar para outras. Ainda mais preocupante é o fato da violência escapar do nível institucional e se apresentar nas relações entre as pessoas. Não se agride somente a religião, os sujeitos também praticam a agressão entre si, nessa busca bélica de afirmar que dicotomias entre certo e errado, bem e mal.

Não nos propomos a abarcar toda a discussão possível dos elementos levantados neste texto. Mas buscamos apontar, não à toa, através de epistemologias pretas, que existem outros caminhos a serem considerados para que o ser humano estabeleça relações de afirmação da vida. Aos modos de Agamben (2007), apostamos na criança como força inventiva, mais curiosa do que dotada de certezas, como abertura para o mundo, na contramão da seriedade e rigidez adultas, que, por vezes, acabam por assassinar modos de vida.

Com Kiriku e Ubuntu, buscamos pensar não somente pela via da tolerância. Como aponta Louro (2004), o discurso de que devemos tolerar a diferença ainda é carregado de um sentido de afastamento do que outro que se coloca de modo diferente. Tolerar não nos parece suficiente, pois pode preservar no sujeito a ideia de que o que se tolera é mesmo inferior. A proposta é colocar as práticas em conversa, entendendo as particularidades, mas possibilitando o diálogo, a contribuição ou minimamente a condição para que o outro exista em sua diferença. É preciso diminuir a urgência de conversão e condenação e se tornar uma criança aberta ao outro e a seus possíveis. Quem se esforça por convencer é o adulto em sua razão, sejamos crianças como Kiriku!

\section{Referências}

AGAMBEN, Giorgio. Profanações. São Paulo: Boitempo, 2007.

BRASIL. Diversidade religiosa é marca da população brasileira. Disponível em: http://www.brasil.gov.br/noticias/cidadania-e-inclusao/2018/01/diversidade-religiosa-emarca-da-populacao-brasileira. 2018. Acesso em: 19/01/2019.

ATHAYDE, Ana Terra. Se em nome de Cristo destroem, em nome de Cristo vamos reconstruir: evangélicos ajudam a reerguer terreiro queimado. BBC. Publicado em: 24 abril 2018. Disponível em: https://www.bbc.com/portuguese/brasil-43879422. Acesso em: 21/01/2019. 
FOUCAULT, Michel. Os anormais. São Paulo: Martins Fontes, 2010.

FOUCAULT, Michel. A ordem do discurso. São Paulo; Edições Loyola, 1996.

KIRIKU E A FEITICEIRA. Direção: Michel Ocelot. Produção: Didier Brunner. França: France 3, 1998. 74 minutos.

LOURO, Guacira Lopes. Um corpo estranho: ensaios sobre sexualidade e teoria queer. Belo Horizonte: Autêntica. 2004

NASCIMENTO, Alessandra Amaral Soares. Candomblé e Umbanda: Práticas religiosas da identidade negra no Brasil. RBSE. v. 9, n. 27, p. 923- 944, 2010.

NOGUERA, Renato. Pinóquio e Kiriku: infância(s) e educação nas filosofia de Kant e Ramose. ALENCAR, Marta Vitória de; CARNEIRO, Silvio Ricardo Gomes; CORREIA, Adriano; PASCHOAL, Antonio Edmilson. (Orgs.). Filosofar e ensinar a filosofar. Coleção XVII Encontro ANPOF.. São Paulo: ANPOF, 2017.

RAMOSE, Mogobe B. Globalização e Ubuntu. In: SANTOS, Boaventura de S.; MENESES, Maria Paula (Orgs.). Epistemologias do Sul. Coimbra: Almedina. 2009.

RESK, Felipe; TOMAZELA, José Maria; COTRIM, Jonathas. ESTADÃO. Brasil registra uma denúncia de intolerância religiosa a cada 15 horas. O Estado de São Paulo, São Paulo, 12 nov. 2017. Disponível em: https://brasil.estadao.com.br/noticias/geral,brasil-registra-uma-denuncia-deintolerancia-religiosa-a-cada-15-horas,70002081286. Acesso em: 19/01/2019.

ROCHA, Geraldo da; SILVA, Cristina Conceição; ALBUQUERQUE, Gabriela Girão de. Ylê ayê orum ubuntu: bebendo das fontes da africanidade. Cadernos do CNLF, Rio de Janeiro, Anais [...] v. XVII, n. 02, 2013.

RODRIGUES, José Carlos. Tabu do Corpo. Rio de Janeiro: Achiamé, 1983.

SOUZA, Marco Antônio de. As estratégias da pedagogia do assistencialismo em Belo Horizonte, 1930-1990: Educação e Caridade. Tese (Doutorado em Educação). Programa de Pós-Graduação de Educação da Universidade Federal de Minas Gerais, 2001.

LARAIA, Roque de Barros. As religiões indígenas: o caso tupi-guarani. Revista USP, São Paulo, n.67, p. 6-13, set-nov. 2005.

TEIXEIRA, Faustino. Fundamentalismo em tempos de pluralismo religioso. In: MOREIRA, Alberto da Silva, OLIVEIRA, Irene Dias (Orgs.). O futuro da religião na sociedade global: uma perspectiva multicultural. São Paulo: Paulinas, 2008.

VAINFAS, Ronaldo; SOUZA, Juliana Beatriz de. Brasil de todos os santos. Rio de Janeiro: Jorge Zahar Ed, 2002. 